ORIGINAL ARTICLE

\title{
PEA-15 unphosphorylated at both serine 104 and serine 116 inhibits ovarian cancer cell tumorigenicity and progression
} through blocking $\beta$-catenin

\author{
$\mathrm{J} \mathrm{Lee}^{1,2}$, C Bartholomeusz ${ }^{1,2}$, S Krishnamurthy ${ }^{3}$, P Liu ${ }^{4}$, H Saso ${ }^{1,2}$, TA LaFortune ${ }^{1,2}$, GN Hortobagyi ${ }^{1,2}$ and NT Ueno ${ }^{1,2}$
}

Ovarian cancer is a major cause of death among women; there remains an urgent need to develop new effective therapies to target this cancer. Phosphoprotein enriched in astrocytes (PEA-15) is a 15-kDa phosphoprotein that is known to bind ERK1/2, thus blocking cell proliferation. The physiological activity of PEA-15 is dependent on the phosphorylation status of serine 104 (Ser104) and Ser116. However, little is known about the impact of PEA-15 phosphorylation on tumor progression. We have previously shown that overexpression of PEA-15 has an antitumor effect against both breast and ovarian cancer cells. Here, we report that using a human ovarian cancer tissue microarray, we found that tissues from patients with ovarian cancer were significantly more likely than adjacent normal tissues to express PEA-15 phosphorylated at both sites. Using phosphomimetic and nonphosphorylatable mutants of PEA-15, we found that mutant double-unphosphorylated PEA-15 in which Ser104 and Ser116 were substituted with alanine (PEA-15-AA) had a more potent antitumorigenic effect in ovarian cancer than did phosphomimetic PEA-15 in which Ser104 and Ser116 were substituted with aspartic acid (PEA-15-DD). Further, we observed that the antitumorigenic effect of PEA-15-AA was a result of inhibition of the migration capacity of cells and inhibition of in vivo angiogenesis. This inhibition was partially dependent on inhibition of $\beta$-catenin expression and nuclear translocalization. Taken together, our results suggest that phosphorylated PEA-15 is an important contributor to the aggressiveness of ovarian cancer and justify the development of PEA-15-AA as an effective therapeutic molecule in the treatment of ovarian cancer.

Oncogenesis (2012) 1, e22; doi:10.1038/oncsis.2012.22; published online 16 July 2012

Subject Category: tumour suppression

Keywords: PEA-15; ovarian cancer; $\beta$-catenin; tumorigenicity; growth inhibition; three-dimensional Matrigel cultures

\section{INTRODUCTION}

Ovarian cancer is a major cause of death among women in the United States (15460 deaths and 21990 new cases estimated in 2011). ${ }^{1}$ Improved treatments are urgently needed for patients with advanced-stage ovarian cancer who do not respond to chemotherapy.

Phosphoprotein enriched in astrocytes (PEA-15) is a $15-\mathrm{kDa}$ phosphoprotein that contains an N-terminal death effector domain and a C-terminal tail with an irregular structure. ${ }^{2}$ In breast cancer, PEA-15 expression inhibits invasion by binding to ERK and preventing its nuclear translocation, and reduced PEA-15 expression was seen in metastatic breast cancer cells. ${ }^{3}$ These observations suggest that PEA-15 is a suppressor of metastasis. We previously reported that the antitumor activity of the adenovirus protein E1A in ovarian cancer was dependent on PEA-15 expression ${ }^{4}$ and that women whose ovarian tumors had high PEA-15 expression survived longer than women whose ovarian tumors had low PEA-15 expression. ${ }^{5}$ In human breast cancers, overexpression of PEA-15 inhibited growth, reduced DNA synthesis and suppressed tumor growth in a xenograft model. ${ }^{6}$

The $92-\mathrm{kDa}$ oncoprotein $\beta$-catenin is an important regulator of cellular adhesion and the Wnt signaling pathway. In fully differentiated cells, $\beta$-catenin mediates cell-cell adhesion via the transmembrane E-cadherin/catenin complex. ${ }^{8,9}$ Abnormal signaling of $\beta$-catenin has been linked to the malignant events in colon cancer, melanomas and ovarian cancer. ${ }^{10}$ Abnormal transcriptional activity of $\beta$-catenin is mediated by insulin, insulinlike growth factor-1, lysophosphatidic acid and Wnt glycoproteins through the $\beta$-catenin/T-cell factor complex in the nucleus. ${ }^{11,12}$ In addition, inhibition of glycogen synthase kinase-3 (GSK-3) by Wnt activation leads to inactivation of the tumor suppressor complex $\mathrm{TSC} 1 / 2$ and results in activation of the mammalian target of rapamycin signaling pathway. ${ }^{13,14}$ Thus, the $W n t / \beta$-catenin signaling pathway can induce target gene expression via both transcriptional and translational mechanisms. These target genes are closely related to malignant behavior.

The physiological activity of PEA-15 is dependent on the phosphorylation status of serine 104 (Ser104) and Ser116. ${ }^{15}$ For example, phosphorylation of PEA-15 at these Ser residues inhibited PEA-15 binding to ERK1/2. ${ }^{16}$ However, little is known about the phosphorylation status of PEA-15 at Ser104 and Ser116 in tumors, and the impact of PEA-15 phosphorylation at Ser104 and Ser116 on tumor progression. In the work reported here, we found using a human ovarian cancer tissue microarray that PEA-15

${ }^{1}$ Breast Cancer Translational Research Laboratory, The University of Texas MD Anderson Cancer Center, Houston, TX, USA; ${ }^{2}$ Department of Breast Medical Oncology, Unit 1354, The University of Texas MD Anderson Cancer Center, Houston, TX, USA; ${ }^{3}$ Department of Pathology, The University of Texas MD Anderson Cancer Center, Houston, TX, USA and ${ }^{4}$ Division of Quantitative Sciences, The University of Texas MD Anderson Cancer Center, Houston, TX, USA. Correspondence: Dr NT Ueno, Department of Breast Medical Oncology, Unit 1354, The University of Texas MD Anderson Cancer Center, 1515 Holcombe Boulevard, Houston, TX 77030, USA.

E-mail: nueno@mdanderson.org

Received 26 January 2012; revised 4 June 2012; accepted 6 June 2012 
phosphorylated at both Ser104 and Ser116 predominantly existed in tumor tissue rather than cancer-adjacent normal tissue. Further, we sought to develop a more potent form of PEA-15 by modifying its two major phosphorylation sites. In a panel of ovarian cancer cell lines, we observed that double-unphosphorylated PEA-15 in which Ser104 and Ser116 were substituted with alanine (PEA-15AA) strongly suppressed tumorigenicity in vitro and in vivo. This effect was significantly stronger than that observed with wild-type PEA-15 (PEA-15-WT) or PEA-15 in which Ser104 and Ser116 were substituted with aspartic acid, which mimics phosphorylation (PEA-15-DD). We found that PEA-15-AA suppressed ovarian cancer cell proliferation, cell network formation (which correlates with migration) and tumor growth and that these effects were partially dependent on inhibition of $\beta$-catenin. Taken together, our current results provide novel insights into the role of PEA-15 in tumorigenicity and suggest that double-unphosphorylated PEA-15 may be a novel effective therapeutic molecule to treat ovarian cancer.

\section{RESULTS}

PEA-15 phosphorylated at both Ser104 and Ser116 is highly expressed in human ovarian cancer tissues

We previously reported that high expression level of PEA-15 correlated with good prognosis in ovarian cancer patients. ${ }^{5}$ However, the level of phosphorylated PEA-15 in human cancer remains unknown. We therefore measured the level of phosphorylated PEA-15 in patients with ovarian cancer using a human ovarian cancer tissue microarray. Patient characteristics are summarized in Table 1. Statistical analysis revealed that total expression of PEA-15 phosphorylated at both Ser104 and Ser116 was significantly higher in high-grade ovarian tumor tissue (grade II, $P=0.002$; grade III, $P=0.001$ ) than in cancer-adjacent normal ovarian tissue (Figure 1; Table 2). We also observed that PEA-15 phosphorylated at Ser104 occurred only in tumor tissue $(P<0.0001)$. There was no significant difference between tumor tissue and cancer-adjacent normal tissue in the prevalence of expression of the other forms of phosphorylated PEA-15 or $\beta$-catenin expression. Taken together, our data indicated that PEA-15 in ovarian tumor cells exists predominantly in the double-phosphorylated form.

PEA-15 overexpression inhibits human ovarian cancer cell proliferation in vitro

On the basis of the results of our tissue microarray analysis, which indicated that PEA-15 phosphorylated at both Ser104 and S116 may be involved in human ovarian cancer progression, we investigated whether artificially modified PEA-15 was capable of inhibiting ovarian cancer cell proliferation.

To choose suitable cell lines for overexpression of artificially modified PEA-15, we first determined the endogenous level of PEA-15 in a panel of ovarian cancer cell lines. Five cell lines-2774, KOC-7c, OVCA420, RMG-1 and SKOV3.ip1-showed lower expression of endogenous PEA-15 than the other cell lines (Supplementary Figure S1). Next, we tested the effect of PEA-15WT, PEA-15-AA (double-unphosphorylated) and PEA-15-DD (mimics phosphorylation) on cell proliferation in low-PEA-15expressing cell lines using the trypan blue exclusion assay. We observed that proliferation of KOC-7C and SKOV3.ip1 cells was significantly inhibited by PEA-15-WT (KOC-7c, 21\%; SKOV3.ip1, 31\%), PEA-15-AA (KOC-7C, 29\%; SKOV3.ip1, 40\%) and PEA-15-DD (KOC-7c, 24\%; SKOV3.ip1, 28\%, $P<0.05$ ), whereas proliferation of OVCA420 cells was significantly inhibited only by PEA-15-AA (23\%, $P<0.05$, Figure 2a).

To further study the role of the PEA-15 double mutants in ovarian cancer, we selected SKOV3.ip1 cells, ${ }^{17}$ because these lowPEA-15-expressing cells exhibit an increased ability to migrate and
Table 1. Patient characteristics

\begin{tabular}{|c|c|c|}
\hline Characteristics & \multicolumn{2}{|c|}{ No. of patients (\%) } \\
\hline \multicolumn{3}{|l|}{$\begin{array}{l}\text { Age }(y) \\
\quad \text { Range, 17-70 } \\
\text { Median, } 51\end{array}$} \\
\hline \multicolumn{3}{|c|}{ Histopathologic diagnosis (adenocarcinoma) } \\
\hline Serous & $\begin{array}{l}47 / 60 \\
(78.3)\end{array}$ & \\
\hline Others (endometrioid, mucinous) & $\begin{array}{l}13 / 60 \\
(21.7)\end{array}$ & \\
\hline $\begin{array}{l}\text { Normal (cancer-adjacent normal } \\
\text { tissue) }\end{array}$ & & 10 \\
\hline \multicolumn{3}{|l|}{ Grade } \\
\hline 1 & $\begin{array}{l}13 / 60 \\
(21.7)\end{array}$ & \\
\hline 2 & $\begin{array}{l}26 / 60 \\
(43.3)\end{array}$ & \\
\hline 3 & $\begin{array}{l}21 / 60 \\
(35.0)\end{array}$ & \\
\hline \multicolumn{3}{|l|}{ Disease stage } \\
\hline 1 & $\begin{array}{l}38 / 60 \\
(63.3)\end{array}$ & \\
\hline II & $\begin{array}{l}18 / 60 \\
(30.0)\end{array}$ & \\
\hline III & $3 / 60(5.0)$ & \\
\hline IV & $1 / 60(1.7)$ & \\
\hline \multicolumn{3}{|l|}{ p-PEA15-S104 expression } \\
\hline 1 (low) & $\begin{array}{l}12 / 60 \\
(20.0)\end{array}$ & $\begin{array}{l}10 / 10 \\
(100)\end{array}$ \\
\hline 2 (moderate) & $\begin{array}{l}22 / 60 \\
(36.7)\end{array}$ & 0 \\
\hline 3 (high) & $\begin{array}{l}26 / 60 \\
(43.3)\end{array}$ & 0 \\
\hline \multicolumn{3}{|l|}{ p-PEA15-S116 expression } \\
\hline 1 (low) & $\begin{array}{l}24 / 60 \\
(40.0)\end{array}$ & $1 / 10(10)$ \\
\hline 2 (moderate) & $\begin{array}{l}20 / 60 \\
(33.3)\end{array}$ & $6 / 10(60)$ \\
\hline 3 (high) & $\begin{array}{l}16 / 60 \\
(26.7)\end{array}$ & $3 / 10(30)$ \\
\hline \multicolumn{3}{|l|}{$\beta$-Catenin expression } \\
\hline 0 (no expression) & $5 / 60(8.3)$ & 0 \\
\hline 1 (low) & $\begin{array}{l}34 / 60 \\
(56.7)\end{array}$ & $5 / 10(50)$ \\
\hline 2 (moderate) & $\begin{array}{l}14 / 60 \\
(23.3)\end{array}$ & $5 / 10(50)$ \\
\hline 3 (high) & $7 / 60(11.7)$ & 0 \\
\hline
\end{tabular}

increase metastatic potential compared with the other low-PEA15-expressing ovarian cancer cells that we studied. After establishing stable transfectants of PEA-15-WT, PEA-15-AA and PEA-15-DD in SKOV3.ip1 cells, we performed the soft agar assay. Both PEA-15-AA and PEA-15-DD inhibited SKOV3.ip1 cell colony formation by more than $80 \%$ compared with the vector control $(P<0.001$, Figure $2 b)$.

PEA-15-AA and PEA-15-DD inhibit projection formation and migration of SKOV3.ip1 cells in three-dimensional (3D) culture Three-dimensional Matrigel cell cultures serve as a good model to study physiologically relevant aspects of the behavior of nonmalignant and malignant cells ex vivo. ${ }^{18}$ We investigated the effects of the PEA-15 double mutants on the projection formation of SKOV3.ip1 cells in 3D Matrigel cultures. PEA-15-AA and PEA-15- 


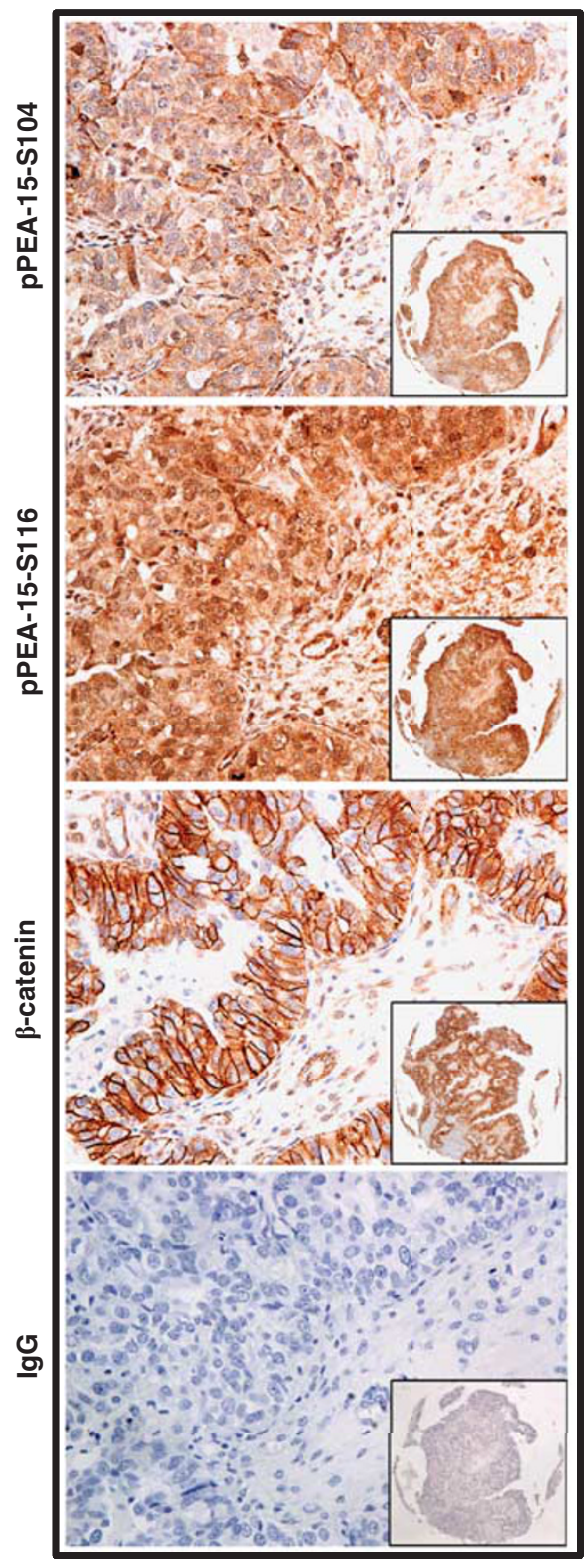

Tumor tissue

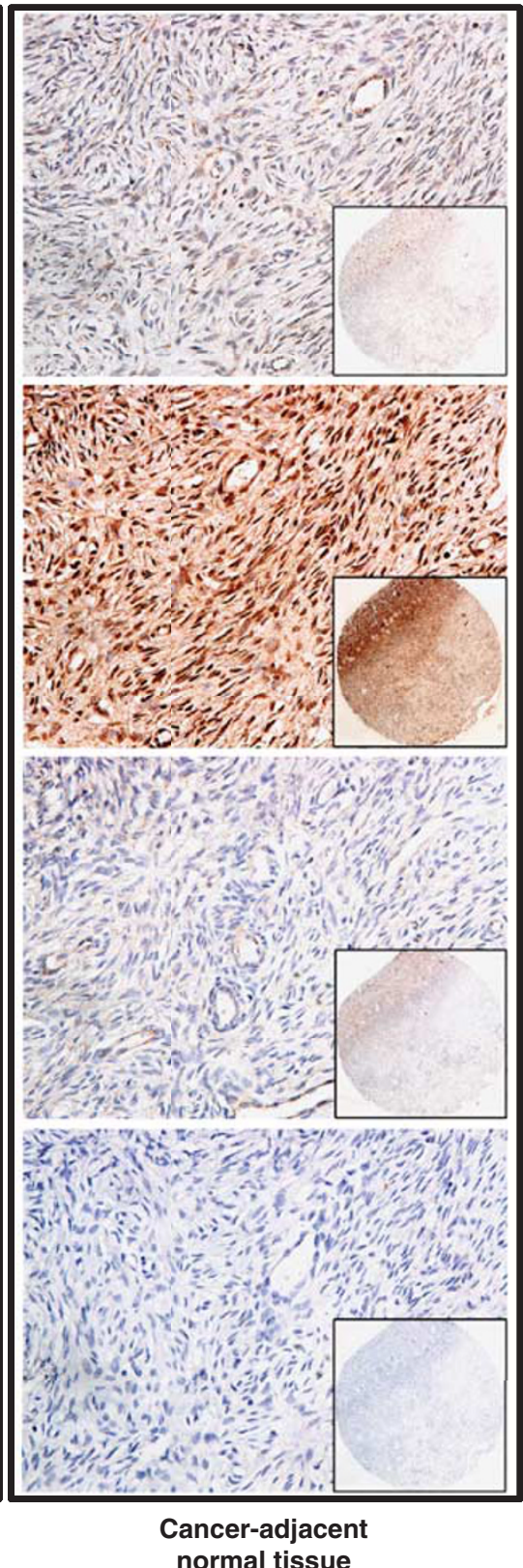

Figure 1. PEA-15 phosphorylated at Ser104 (pPEA-15-S104) and PEA-15 phosphorylated at Ser116 (pPEA-15-S116) were highly overexpressed in high-grade ovarian tumor tissues. Immunohistochemical staining shows the expression level of pPEA-15-S104, pPEA-15-S116 and $\beta$-catenin in ovarian tumor tissue and cancer-adjacent normal tissue. Original magnification, $\times 200$ (insets, $\times 40$ ).

DD reduced projection formation by about $80-90 \%(P<0.01)$ compared with the vector control (Figure $2 c)$. Time-lapse video data clearly showed an inhibitory effect of PEA-15-AA on 3D projection formation compared with the vector control (Supplementary Movies 1 and 2).

As PEA-15-AA and PEA-15-DD strongly inhibited projection formation, we hypothesized that they would also influence SKOV3.ip1 cell migration. To test this concept, we performed a migration assay in SKOV3.ip1 stable transfectants. We observed that PEA-15-AA and PEA-15-DD reduced cell migration by $60-80 \%$ $(P<0.05)$ compared with the vector control (Figure $2 \mathrm{~d}$ ). Taken together, these data demonstrated that PEA-15-AA and PEA-15DD inhibit cell-to-cell interaction and migration of SKOV3.ip1 ovarian cancer cells.
PEA-15-AA inhibits tumor growth in an ovarian cancer xenograft model

In an attempt to identify a form of PEA-15 that would be more potent against ovarian cancer, we examined the effects of PEA-15$\mathrm{AA}$ and PEA-15-DD in vivo. When stable transfectants of SKOV3.ip1 cells stably transfected with vector control, PEA-15-AA or PEA-15DD were injected intraperitoneally into nude mice, we found that $90-100 \%$ of the mice injected with the cells stably transfected with vector or PEA-15-DD but only $40 \%$ of the mice injected with cells stably transfected with PEA-15-AA developed tumors (Figures $3 \mathrm{a}$ and $\mathrm{b}, P=0.02$ ). To confirm these findings, we tested one more stable clone of each stable cell line (PEA-15-WT, PEA-15-DD-3 and PEA-15-AA-1). We observed results similar to the results shown in Figure $3 a$, further confirming that PEA-15-AA has a strong 
Table 2. Summary of statistics for phospho-PEA-15 and $\beta$-catenin expression ${ }^{\text {a }}$

\begin{tabular}{|c|c|c|c|c|}
\hline Analysis categories & \multicolumn{2}{|c|}{ Tumor $\mathrm{n}(\%)$} & Normal n (\%) & $\begin{array}{c}\mathrm{P} \\
\text { Normal vs tumor }\end{array}$ \\
\hline \multicolumn{5}{|l|}{ Tumor grade } \\
\hline 1 & $10 / 13$ & $3 / 13$ & & 0.0004 \\
\hline II & $20 / 26$ & $6 / 26$ & & $<0.0001$ \\
\hline III & $18 / 21$ & $3 / 21$ & & $<0.0001$ \\
\hline \multicolumn{5}{|l|}{ Double phopshorylation status } \\
\hline PEA-15 high-pS104/low-pS116 & $17 / 60(25.8)$ & & $0 / 10(0.0)$ & 0.1043 \\
\hline PEA-15 low-pS104/high-pS116 & $2 / 60(3.3)$ & & $9 / 10(90.0)$ & \\
\hline \multicolumn{5}{|l|}{ Tumor grade } \\
\hline 1 & $0 / 13$ & & & $<0.001$ \\
\hline \multicolumn{5}{|l|}{ Tumor grade } \\
\hline 1 & $5 / 13$ & & & 0.046 \\
\hline$\|$ & $15 / 26$ & & & 0.002 \\
\hline III & $13 / 21$ & & & 0.001 \\
\hline PEA-15 low-pS104/low-pS116 & $8 / 60(13.3)$ & & $1 / 10(10.0)$ & 1 \\
\hline
\end{tabular}

antitumor effect compared with PEA-15-WT or PEA-15-DD $(P<0.0001$, Supplementary Figure S4).

Transition into an aggressive cancer cell requires alterations in morphology, cellular architecture, adhesion and migration capacity. ${ }^{19}$ We hypothesized that the observed suppression of SKOV3.ip1 cell projection formation and migration by PEA-15-AA and PEA-15-DD (Figures $2 c$ and $d$ ) involves inhibition of the epithelial-mesenchymal transition (EMT) pathway. To test this hypothesis, we investigated EMT gene expression patterns by western blotting. We observed that both PEA-15-AA and PEA-15-DD inhibited $\mathrm{E}$-cadherin, $\mathrm{N}$-cadherin and vimentin expression compared with vector control in SKOV3.ip1 cells in 3D Matrigel culture (data not shown). However, only PEA-15-AA strongly inhibited expression of $\beta$-catenin (data not shown), which is a key molecule in the Wnt signaling pathway and is important in EMT, cellular proliferation and differentiation. ${ }^{1,19}$ We then used immunohistochemical staining to test the expression level of $\beta$-catenin and Ki-67 (cell proliferation marker) in the tumors that formed in the nude mice injected with stably transfected SKOV3.ip1 cells. As expected, expression of $\beta$-catenin and $\mathrm{Ki}-67$ was inhibited in PEA15-AA-expressing tumors compared with vector control or PEA-15DD-expressing tumors (Figure $3 c$ ). These data suggested that PEA$15-A A$ inhibits tumor growth by targeting the $\beta$-catenin pathway.

PEA-15-AA inhibits $\beta$-catenin expression and translocation into the nucleus

Our observation that PEA-15-AA inhibited $\beta$-catenin expression in xenograft tumor tissue samples (Figure $3 \mathrm{c}$ ) prompted us to further investigate the mechanism of $\beta$-catenin regulation by PEA-15-AA in SKOV3.ip1 cells. We first performed an immunoblot assay with total and fractionized cell lysates from stably transfected SKOV3.ip1 cells. Compared with vector-transfected cells, PEA-15AA-expressing cells showed a $47 \%$ reduction of total $\beta$-catenin amount (Figure $4 \mathrm{a}$ ) and a $66 \%$ inhibition of translocation of $\beta$-catenin into the nucleus (Figure $4 b$ ). These results were further confirmed by immunofluorescence staining (Figure 4c).
Next, to examine the effects of PEA-15 mutants on the transcriptional regulation of $\beta$-catenin, we performed quantitative RT-PCR analysis. We observed no significant changes in $\beta$-catenin mRNA level in the cell lines stably expressing PEA-15-AA or PEA15-DD (Figure 4d). As unphosphorylated GSK-3 $\beta$ is known to phosphorylate $\beta$-catenin, targeting it for proteasomal degradation, we checked the phosphorylation status of GSK-3 $\beta$ at Ser9. PEA-15AA inhibited Ser9 phosphorylation by approximately $90 \%$, whereas PEA-15-DD inhibited Ser9 phosphorylation weakly $(\sim 50 \%$, Figure $4 \mathrm{e})$. As $\beta$-catenin stability depends on its phosphorylation status at Ser residues, we investigated the phosphorylation status of $\beta$-catenin at the different Ser residues (Ser33, Ser37, Ser41, Ser45, Ser552 and Ser675) in stably transfected SKOV3.ip1 cells. PEA-15-AA inhibited $\beta$-catenin phosphorylation at Ser675 by approximately $60-80 \%$ (Figure $4 \mathrm{e}$ ) but did not affect the other Ser residues (data not shown); PEA-15-DD had no effect on the phosphorylation status of the Ser residues (Figure $4 \mathrm{e}$ and data not shown). These data indicated that PEA-15AA may regulate $\beta$-catenin expression through signal pathways other than GSK3- $\beta$.

PEA-15-AA suppresses migration capacity through $\beta$-catenin and suppresses angiogenesis in vivo

Our in vitro and in vivo data (Figures 3 and 4) indicated that PEA15-AA-mediated depletion of $\beta$-catenin correlated with decreased migration, decreased cell-to-cell interaction and tumor growth suppression. To confirm the impact of $\beta$-catenin on proliferation and projection formation in SKOV3.ip1 cells, these cells were treated with small interfering RNA (siRNA) against $\beta$-catenin. The cells in which $\beta$-catenin was knocked down proliferated approximately $30-40 \%$ more slowly than scrambled-siRNA-treated cells (Figure $5 \mathrm{a}, P<0.05$ ). In addition, cells with $\beta$-catenin knockdown showed approximately $60 \%$ less projection formation than the control cells (Figure 5b, $P=0.001$ ). To confirm that $\beta$-catenin knockdown results in reduction in $3 D$ projection formation, we treated cells with the $\mathrm{Wnt} / \beta$-catenin inhibitor pyridium pamoate. 

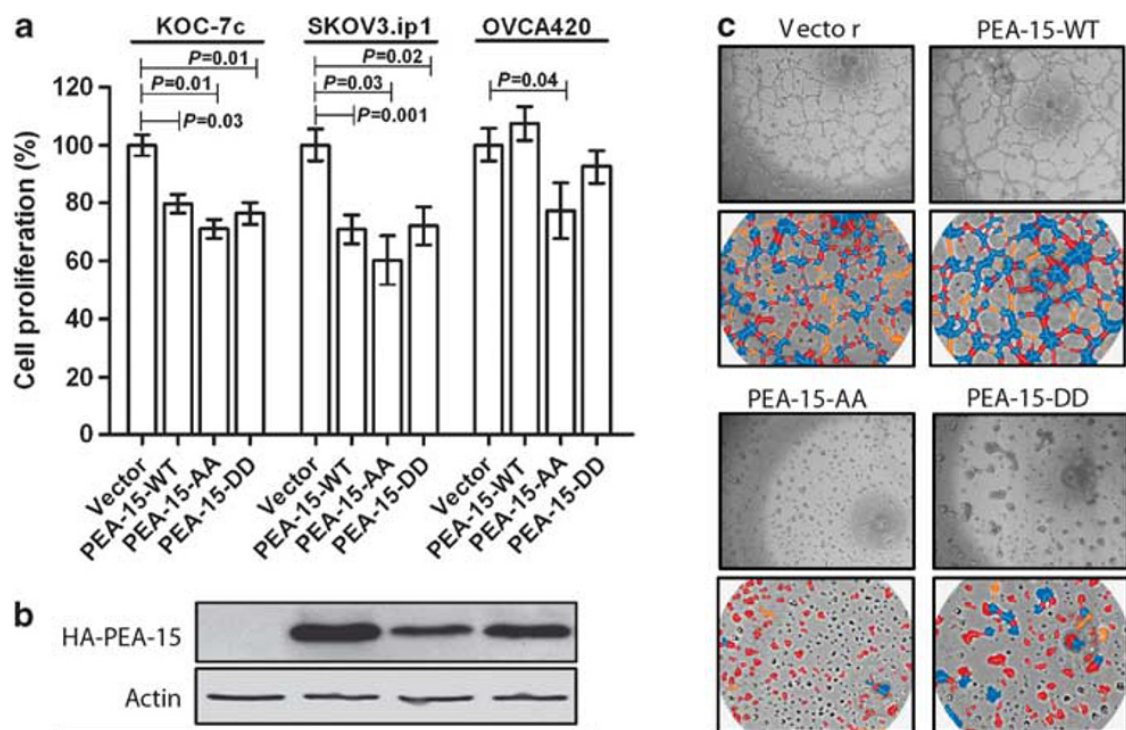

PEA-15-DD
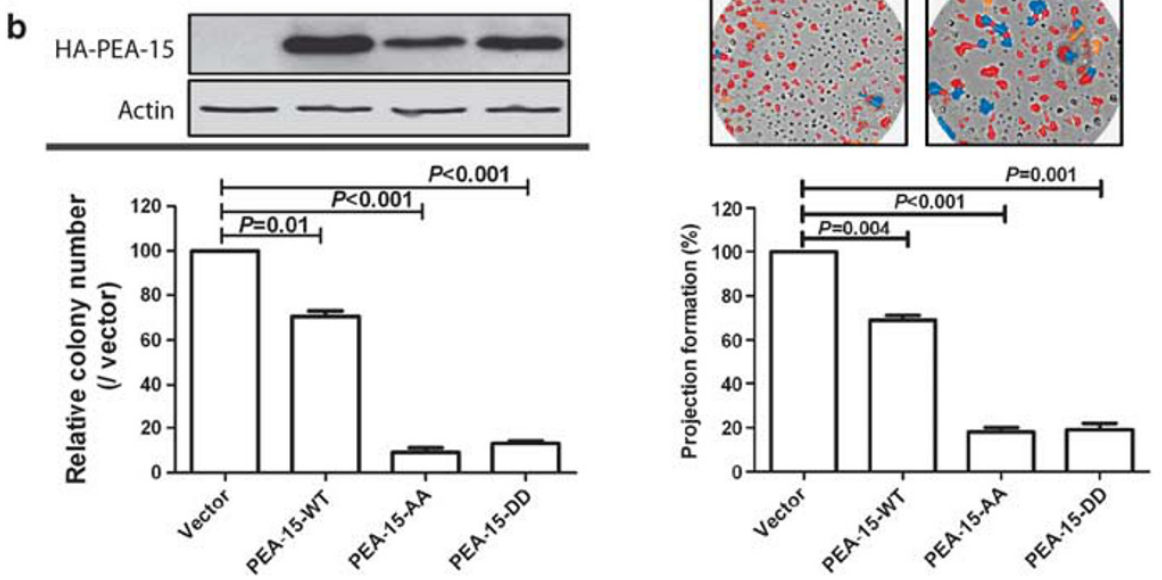


Figure 2. PEA-15-AA and PEA-15-DD inhibited cell proliferation and anchorage-independent growth. (a) Cells were transiently transfected with vector, PEA-15-WT, PEA-15-AA or PEA-15-DD for $72 \mathrm{~h}$, and then cells $\left(5 \times 10^{4}\right)$ were plated into a six-well plate. After $72 \mathrm{~h}$, cell numbers were counted by trypan blue staining. (b) In vitro tumorigenicity (soft agar) assay. Stably transfected SKOV $3 . i p 1$ cells $\left(2 \times 10^{3}\right)$ were seeded into soft agar and incubated for 3 weeks. Colonies were stained with $200 \mathrm{ml}$ of iodo-nitrotetrazoliumchloride $(1 \mathrm{mg} / \mathrm{ml}) \mathrm{for}$ overnight, and the number of colonies over $80 \mathrm{~mm}$ in diameter was counted using the GelCount colony counting system according to the manufacturer's instructions. (c) Three-dimensional Matrigel culture assay. Cells $\left(2 \times 10^{4}\right)$ were added onto the $\mu$-Slide plate (ibidi GmbH) according to the manufacturer's instructions. Blue indicates nodal structure; yellow, well-developed tube formation; red, poorly developed tube formation. (d) Migration assay. Cells $\left(1 \times 10^{5}\right)$ were added into the upper well and $10 \%$ FBS was added into the lower well as an attractants. After a 6-h incubation, migrated cells were stained and counted. Columns, mean; bars, standard deviation. Statistical significance was evaluated by paired $t$-test using GraphPad Prism software. Data shown are representative of three experiments with similar results.

Cells treated with the Wnt/ $\beta$-catenin inhibitor exhibited approximately $50 \%$ less projection formation than control cells (Figure $5 c$, $P=0.01)$. Next, we examined whether this suppression of 3D projection formation was $\beta$-catenin dependent by restoring $\beta$-catenin expression in cells stably transfected with PEA-15-AA. Indeed, PEA-15-AA cells transiently transfected with $\beta$-catenin plasmid recovered projection ability (approximately $40 \%$, $P=0.003)$ and colony formation ability $(P=0.01)$ more than the vector control cells (Figures $5 \mathrm{~d}$ and e). These data indicated that cell migration capacity is partially dependent on $\beta$-catenin.

Activation of Wnt signaling results in subsequent stabilization of $\beta$-catenin and translocation into the nucleus. Within the nucleus, $\beta$-catenin activates target genes such as $c-m y c_{1}^{20}$ cyclin $D_{1}^{21}$ matrix metalloproteinase-7 (MMP-7) $)^{22}$ and cyclooxygenase- $2 .{ }^{23}$ We tested the effect of PEA-15-AA-regulated $\beta$-catenin inhibition on expression of genes involved in angiogenesis and invasion, including c-met, c-myc and MMP-7, using quantitative RT-PCR (c-met and c-myc) or immunohistochemistry (MMP-7). We found that c-met, c-myc and MMP-7 were significantly reduced in PEA-15-AAexpressing cells or primary mouse tumor tissues compared with control cells transfected with vector (Supplementary Figure S2, $P<0.01)$. On the basis of these observations indicating that PEA-15AA reduced expression of angiogenesis- and invasion-related genes, we hypothesized that PEA-15-AA inhibits new microvessel formation in a SKOV3.ip1 xenograft model. To test this hypothesis, we assessed the extent of microvessels in xenograft tumor samples using immunohistochemical staining with CD31, an endothelial cell surface marker that reflects new blood vessel formation. ${ }^{24}$ We observed that PEA-15-AA reduced the number of CD31-stained cells by $80 \%$ compared with vector control or PEA-15-DD (Figure $5 f$, $P<0.05)$. These data indicated that PEA-15-AA suppresses $\beta$-catenin expression and inhibits angiogenesis.

\section{DISCUSSION}

In this study, we found that PEA-15 phosphorylated at both Ser104 and Ser116 is a potential contributor to the aggressiveness of ovarian cancer. We showed that expression of PEA-15 phosphorylated at both Ser104 and Ser116 was significantly more common in high-grade ovarian tumor tissue than in adjacent normal ovarian tissue. Further, PEA-15-AA, but not PEA-15-DD, strongly inhibited tumor growth compared with vector control in an in vivo xenograft model. This ovarian cancer tumorigenicity suppression by PEA-15-AA was a result of inhibition of $\beta$-catenin expression and nuclear translocalization and subsequent inhibition of 
a

\begin{tabular}{c|c|c}
\hline & No. of mice & $\begin{array}{c}\text { Incidence of tumor } \\
\text { formation }(\%)\end{array}$ \\
\hline Vector & $9 / 10$ & $90 \%$ \\
\hline PEA-15-AA & $6 / 15$ & $40 \%$ \\
\hline PEA-15-DD & $16 / 16$ & $100 \%$ \\
\hline
\end{tabular}

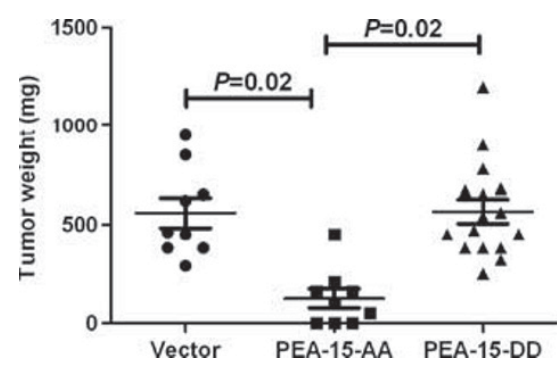

b

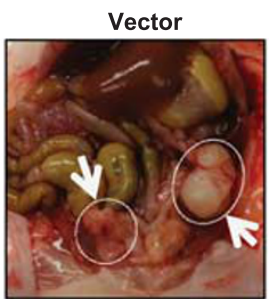

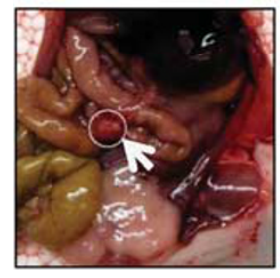

PEA-15-AA

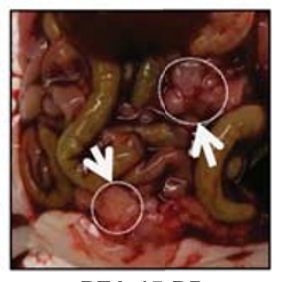

PEA-15-DD c

c

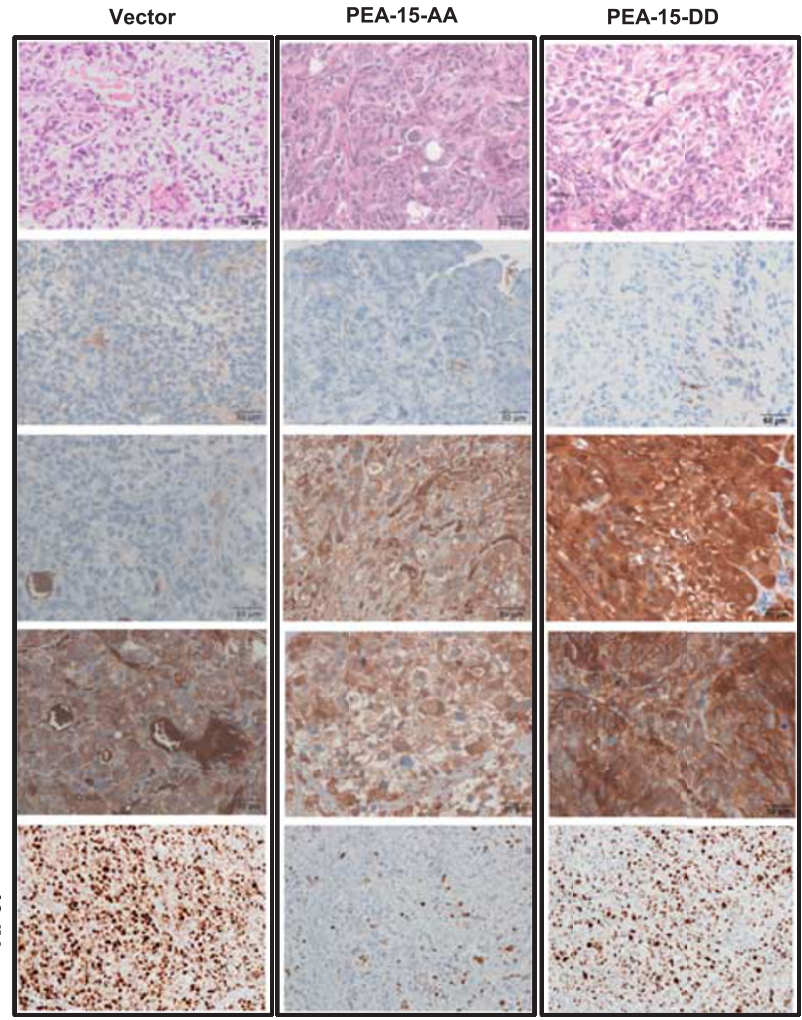

Figure 3. PEA-15-AA has a strong antitumor effect in an ovarian cancer xenograft model. (a) Upper panel, incidence of tumor formation. Lower panel, tumor weights were significantly smaller with PEA-15-AA than with vector and PEA-15-DD. (b) Representative images showed tumor formation of SKOV3.ip1-vector, SKOV3.ip1-PEA-15-AA and SKOV3.ip1-PEA-15-DD cells in mouse peritoneal area. White arrows indicate tumors. (c) Immunohistochemical staining of HA, $\beta$-catenin and Ki-67 in tumor samples from the xenograft model. H\&E, hematoxylin-eosin. Scale bars: $50 \mu \mathrm{m}$. Statistical significance was evaluated by paired $t$-test using GraphPad Prism software.

angiogenesis. Suppression of migration capacity by PEA-15-AA was partially dependent on $\beta$-catenin.

The structure of PEA-15 suggests that phosphorylation status could regulate its intracellular signaling pathway. The C-terminus of PEA-15 contains two major Ser residues, Ser104 and Ser116, that are required for ERK binding. Our group and others have shown that PEA-15 reduces the transcriptional activity of ERK by inhibiting the transcription factor Elk-1, which regulates ERKdependent transcription. ${ }^{4,25-28}$ Renganathan et al. ${ }^{29}$ reported that phosphorylation at Ser104 blocks ERK binding to PEA-15 in vitro and in vivo. These authors also demonstrated that double phosphorylation of PEA-15 at Ser104 and Ser116 switches the binding specificity of PEA-15 from ERK to FADD. Trencia et al. ${ }^{30}$ observed that protein kinase B/AKT can bind and phosphorylate Ser116 on PEA-15, thereby stabilizing its antiapoptotic function. They demonstrated that simultaneous increases in PEA-15 cellular levels and AKT activity might function cooperatively in tumorigenesis or tumor progression in humans. These findings indicated that PEA-15 phosphorylation status at Ser104 and at Ser116 may be important in transduction of survival signals, which supports an important role of PEA-15 in the cellular regulation of apoptotic programs. Therefore, we asked ourselves whether PEA15 with modulated phosphorylation status at Ser104 and Ser116 could result in more potent suppression of tumorigenicity than wild-type PEA-15 in ovarian cancer cells. In the study reported here, we found that only the double-unphosphorylated form, PEA-15-AA, strongly inhibited tumor growth and Ki-67 expression, which is strictly associated with cell proliferation. These data support the hypothesis that PEA-15-AA could be specifically developed as a therapeutic agent for ovarian cancer.

Our in vitro data showed that PEA-15-AA and PEA-15-DD had similar inhibitory effects in a 2D culture system. However, our in vivo data showed that only PEA-15-AA had a strong antitumor effect. Cukierman et al. ${ }^{31}$ observed that 3D culture condition enhanced cell adhesion, thereby more than doubling cell proliferation compared with 2D culture condition. Furthermore, Formisano et al. ${ }^{32}$ reported that PEA-15 phosphorylated at $\mathrm{S} 104$ and S116 interacted with laminin receptor, resulting in cell adhesion, migration and proliferation. Thus, although we do not have direct evidence to explain the difference in results between the $2 \mathrm{D}$ culture system and the in vivo test condition, we speculate that the difference is due to tumor microenvironmental condition.

$\beta$-Catenin expression is tightly regulated by an APC/GSK-3 $\beta$ / Axin protein complex through a ubiquitin-proteasome pathway. ${ }^{33,34}$ Without Wnt pathway activation, GSK-3 $\beta$ induces $\beta$-catenin phosphorylation at Ser33, Ser37 and Thr41; thereby, $\beta$-catenin is constantly degraded by the proteasome. ${ }^{35} \mathrm{GSK}-3$ is one of the primary downstream targets of the PI3 kinase/AKT axis. AKT-mediated phosphorylation of GSK-3 $\alpha$-Ser21/GSK-3 $\beta$-Ser9 induced cell survival by destruction of $\beta$-catenin regulation. ${ }^{36}$ Our data showed that although both PEA-15-AA and PEA-15-WT suppressed and PEA-15-DD weakly suppressed phosphorylation of GSK-3 at Ser9, only PEA-15-AA dramatically inhibited total expression and translocalization of $\beta$-catenin. These data 

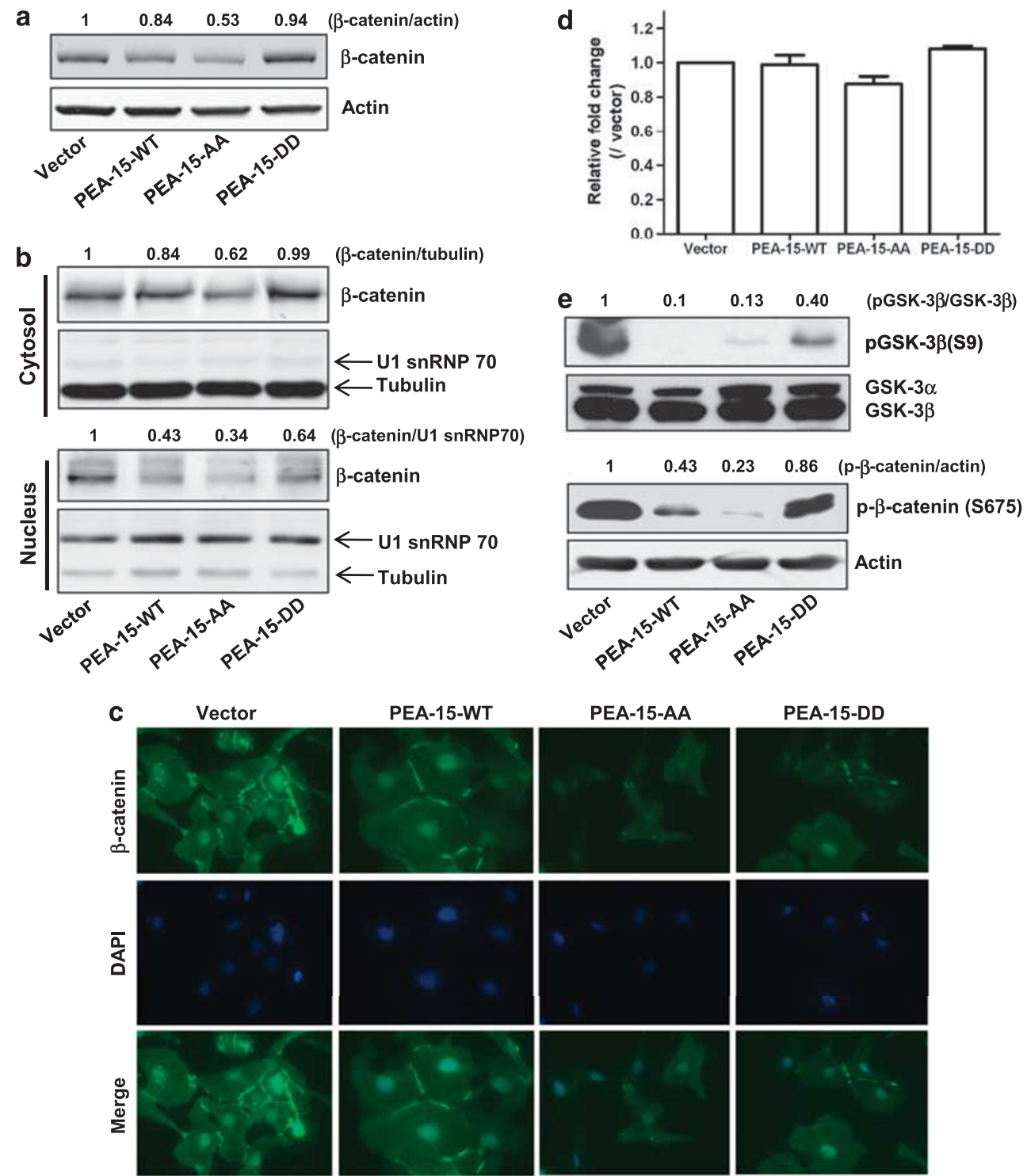

Figure 4. PEA-15-AA inhibited $\beta$-catenin expression and translocalization. (a) Total $\beta$-catenin expression level in stably transfected SKOV3.ip1 cells. Fifteen micrograms of lysate was loaded. The expression levels of $\beta$-catenin for each cell line were evaluated using LI-COR software. (b) PEA-15-AA inhibited translocalization of $\beta$-catenin into the nucleus. Cytosolic and nuclear fractions were prepared as described in Materials and methods. For loading control, tubulin (for cytosolic fraction) and U1 snRNP 70 (for nuclear fraction) were used. (c) Immunofluorescence staining. Stably transfected SKOV3.ip1 cells were grown on the four-well slide chamber for overnight, and immunofluorescence staining was performed as described in Material and methods. (d) Quantitative RT-PCR analysis of $\beta$-catenin mRNA level in stably transfected SKOV3.ip1 cells. (e) Western blotting. Effect of different forms of PEA-15 on GSK-3 $\beta$ phosphorylation at Ser9 and $\beta$-catenin phosphorylation at Ser675.

indicated that PEA-15-AA-mediated $\beta$-catenin inhibition could be regulated by a pathway other than GSK-3 regulation. Other groups previously reported that protein kinase B/AKT can phosphorylate $\beta$-catenin at Ser552 and that CAMP-dependent protein kinase (PKA) phosphorylates $\beta$-catenin at Ser552 and Ser675. ${ }^{37-39}$ Phosphorylation at Ser552 and Ser675 induces $\beta$-catenin translocation into the nucleus from the cytosol and increases its transcriptional activity. ${ }^{39,40}$ Cheadle et al. ${ }^{41}$ reported that the PKA- $\alpha$ subunit exhibited hyperproliferative growth in ovarian cancer cells. Thus, although we do not provide direct evidence of involvement of PKA signaling in PEA-15-AA-mediated $\beta$-catenin inhibition, we speculate that the Ser675 residue on $\beta$-catenin is a major target in PEA-15-AA-induced $\beta$-catenin inhibition in ovarian cancer cells. Further studies are needed to determine whether PEA-15$A A$-induced $\beta$-catenin inhibition results in suppression of PKA activity.
We showed here that PEA-15-AA strongly suppressed translocalization of $\beta$-catenin into the nucleus. Nuclear $\beta$-catenin has a transcriptional activity with its co-activator, T-cell factor/lymphocyte enhancer factor- $1 .{ }^{11} \mathrm{Wnt} / \beta$-catenin target genes are related to invasion/metastasis, angiogenesis and EMT. ${ }^{42}$ Rosano et al. ${ }^{43}$ reported that endothelin-1 promotes EMT and enhances invasive phenotype in ovarian cancer cells. Previously, Yoshida et al. ${ }^{44}$ reported that $\beta$-catenin target genes, including c-myc, PPAR, VEGF and axin-2, are correlated with poor prognosis of epithelial ovarian carcinoma. Skurk et al. ${ }^{45}$ showed that GSK-3 $\beta / \beta$-catenin promotes angiogenesis through VEGF in endothelial cells. Zohny and Fayed $^{46}$ suggested that circulating MMP-7 is a marker for diagnosis of epithelial ovarian carcinoma. MMP-7 is involved in shedding, activation or releasing of bioactive molecules, including TNF- $\alpha$, HB-EGF, VEGF and angiotensin. ${ }^{47}$ Our findings are consistent with the above findings as PEA-15-AA inhibited cell- 
a
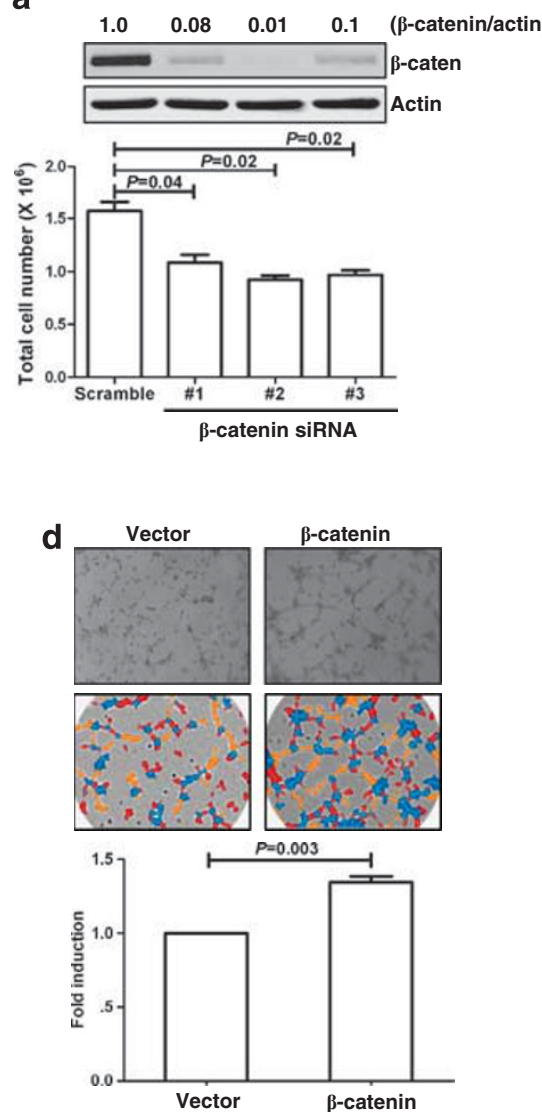

b

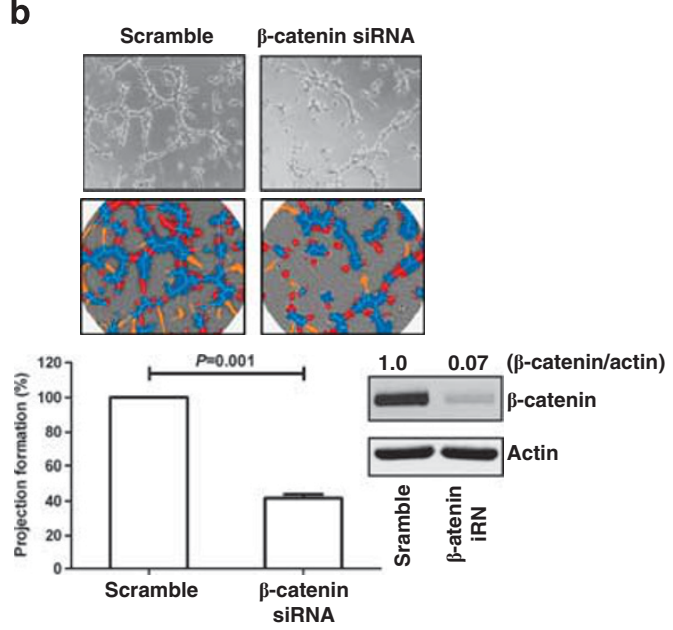

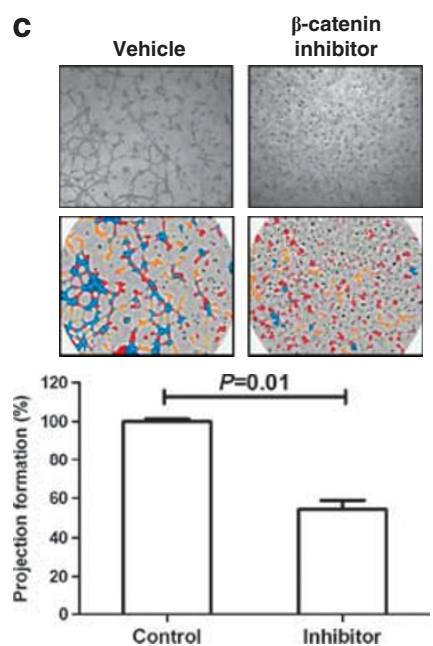

f vector

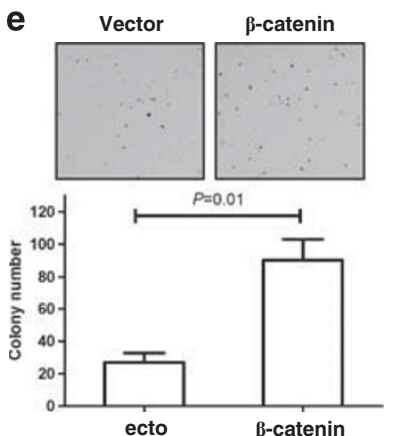

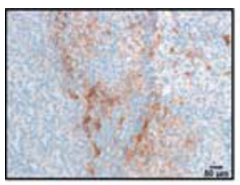

PEA-15-DD
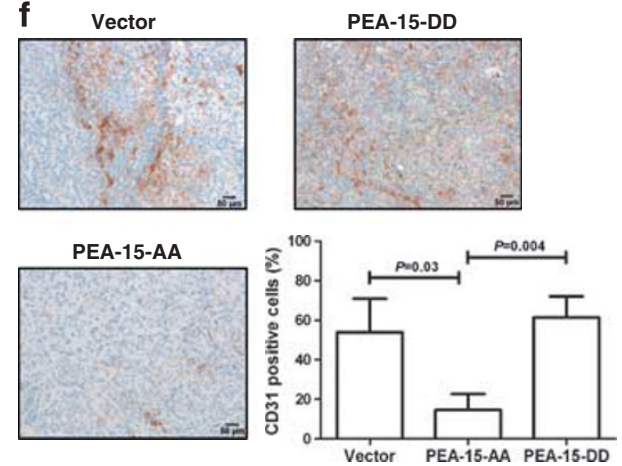

Figure 5. Inhibitory effect of PEA-15-AA on ovarian cancer proliferation, migration capability and angiogenesis is dependent on $\beta$-catenin inhibition. (a) $\beta$-Catenin siRNA inhibited SKOV3.ip 1 cell proliferation. After $48 \mathrm{~h}$ transfection with siRNA, cells were trypsinized, and $1 \times 10^{5}$ cells were plated. Total cell numbers were counted after $48 \mathrm{~h}$. (b) $\beta$-Catenin siRNA inhibited SKOV3.ip1 cell projection formation. (c) Wnt/ $\beta$-catenin inhibitor suppressed SKOV3.ip1 cell projection formation. Cells were pretreated with $1 \mu \mathrm{M}$ of pyridium pamoate (Sigma-Aldrich) for $1 \mathrm{~h}$, and $3 \mathrm{D}$ projection formation assay was performed. (d, e) Rescue of $\beta$-catenin expression in PEA-15-AA stable clones recovered projection formation ability (d) and colony formation ability (e). Cells were transiently transfected with $\beta$-catenin plasmid, and then $3 D$ projection formation assay and colony formation assay were performed. (f) PEA-15-AA strongly reduced the number of CD31-positive cells. Columns, mean; bars, standard error. Scale bars: $50 \mu \mathrm{m}$. Statistical significance was evaluated by paired $t$ test using GraphPad Prism software. Data shown are representative of three experiments with similar results.

to-cell interaction and migration of SKOV3.ip1 cells. Quantitative RT-PCR and immunohistochemical data showed that several $\beta$-catenin target genes, including MMP-7, c-myc and c-met, were inhibited in PEA-15-AA-expressing cells (Supplementary Figure S2A and B). Furthermore, CD31 expression was strongly suppressed in xenograft tumor samples that stably expressed PEA-15AA. These data indicated that PEA-15-AA suppresses angiogenesis by inhibition of $\beta$-catenin expression.

In previous studies of tissue microarrays consisting of samples from patients with breast or ovarian cancer, loss of PEA-15 expression correlated with increased invasiveness, ${ }^{3}$ high nuclear grade and negative hormone receptor status, ${ }^{6}$ and poor overall survival. ${ }^{5}$ The structural analysis of PEA-15 suggested that its phosphorylation status could regulate its biological activity. Phosphorylation on Ser104 and Ser116 is required for ERK binding ${ }^{25-27,48,49}$ and regulation of autophagy via the JNK pathway. ${ }^{50}$ However, to our knowledge, there has been no prior report about the phosphorylation status of PEA-15 in patient samples. Although our tissue microarray was not linked with patient outcome data, we are the first to report that expression of PEA-15 phosphorylated at both Ser104 and Ser116 was significantly more common in ovarian tumor tissue than in adjacent normal ovarian tissue. Furthermore, we also found a similar pattern in a breast cancer patient tissue microarray (Supplementary Figure S3). These data indicate that double- phosphorylated PEA-15 is associated with ovarian cancer and breast cancer tumorigenicity. Further studies are warranted to determine the correlation between the phosphorylation status of PEA-15 and overall survival in patients with ovarian and breast cancer.

As indicated by several previously reported studies, abnormal signaling of $\beta$-catenin has been linked to the malignant events in many types of cancer. ${ }^{10}$ Our tissue microarray analysis showed that phosphorylation at S104 was predominantly observed in ovarian tumor tissues. As there was no significantly difference in $\beta$-catenin expression between cancer and normal tissues, we next analyzed whether $\beta$-catenin expression level was significantly different between double-unphosphorylated PEA-15 and PEA-15 phosphorylated at $\mathrm{S} 104$ in tumor tissue samples. Owing to the small sample size, the results were not statistically significant (Supplementary Table S1). However, we observed trends suggesting that high expression of $\beta$-catenin correlated with phospho$\mathrm{S} 104$ status in tumor tissue samples (high expression was observed in $2(25 \%)$ of the 8 samples with PEA-15-AA, $7(41.2 \%)$ of the 17 samples with PEA-15-DA and 11 (33.3\%) of 33 samples with PEA-15-DD). These observations supported our in vitro data that low expression level of $\beta$-catenin was observed in PEA-15-AAoverexpressing cell lines.

In conclusion, PEA-15-AA inhibits $\beta$-catenin expression and translocation into the nucleus, thereby inhibiting tumorigenicity. 
PEA-15-AA is more potent than PEA-15-DD in suppressing ovarian cancer cell growth in vitro and in vivo through $\beta$-catenin inhibition. Our findings from the tissue microarray study provide a foundation for investigating whether PEA-15 phosphorylated at both Ser104 and Ser116 can serve as a novel biomarker for predicting clinical outcomes in patients with ovarian and breast cancer and for developing innovative PEA-15-AA-based therapy for ovarian cancer.

\section{MATERIALS AND METHODS}

\section{Cell lines}

Human ovarian cancer cell lines 2774, HEY, KOC-7c, OVCA420, OVCA432, OVTOKO, RMG-1 and SKOV3.ip1 were provided by Dr Robert Bast of MD Anderson Cancer Center. Cells were maintained in RPMI 1640 or DMEM/ F12 medium containing 10\% FBS (Sigma-Aldrich, St Louis, MO, USA) and $1 \%$ penicillin/streptomycin (Invitrogen, Grand Island, NY, USA) at $37^{\circ} \mathrm{C}$ in a humidified atmosphere containing $5 \% \mathrm{CO}_{2}$.

\section{Transfection}

SKOV3.jp1 cells were transfected with expression plasmids containing empty vector (pcDNA3-HA), PEA-15-WT (pcDNA3-HA-PEA-15-WT), PEA-15AA (pcDNA3-HA-PEA-15-AA) or PEA-15-DD (pcDNA3-HA-PEA-15-DD) using Lipofectamine 2000 (Invitrogen) according to the manufacturer's instructions. Two days after transfection, medium was exchanged for selective medium containing G418 (Invitrogen) at a final concentration of $800 \mu \mathrm{g} / \mathrm{ml}$. Thereafter, selective medium was exchanged for fresh selective medium every 3 days. Ectopic expression of each gene in the stable cell lines was confirmed by western blot analysis with anti-HA antibody (Covance, Princeton, NJ, USA).

\section{Antibodies}

Antibodies were purchased as follows: PEA-15, CD31, pPEA-15-S104, GSK-3 $\beta, \Delta$ phospho-GSK-3 $\beta, \beta$-catenin and phospho- $\beta$-catenin, Cell Signaling, Danvers, MA, USA; anti-HA, Covance; $\beta$-actin, (clone AC-15), SigmaAldrich; Ki-67, Lab Vision, Kalamazoo, MI, USA; pPEA-15-S116 and Alexa Fluor 488, Invitrogen.

\section{In vitro cell proliferation assay}

For in vitro cell proliferation experiments, trypan blue exclusion assay was performed using Vi-CELL series cell viability analyzers (Beckman Coulter, Brea, CA, USA) according to the manufacturer's instructions.

\section{Western blot analysis}

Western blot analysis was performed as described in Supplementary methods.

\section{Immunohistochemistry and immunofluorescence}

Immunohistochemistry and immunofluorescence studies were performed as described in Supplementary methods.

\section{Small interfering RNA}

Three different sequences of human $\beta$-catenin siRNA (accession no. NM_001098209) were used (Sigma-Aldrich): $5^{\prime}$-GUUAUGGUCCAUCAGCUU U[dT][dT]-3', 5'-CUCAGAUGGUGUCUGUAU[dT][dT]-3' and $5^{\prime}$-GAAUGAAGG UGUGGCGACA[dT][dT]-3'. Cells with $60-70 \%$ confluence were transfected for 7 days with a final concentration of $100 \mathrm{nM} \beta$-catenin siRNA or nonspecific control pooled siRNAs using Lipofectamine RNAMAX transfection reagent (Invitrogen) according to the manufacturer's instructions.

\section{Human tumor samples}

We obtained tissue microarray slides containing specimens of primary ovarian cancer and cancer-adjacent normal ovarian tissues from US Biomax, Inc (Rockville, MD, USA). We only included in our analysis patients who had serous, mucinous or endometrioid adenocarcinoma and a disease stage of I-III. Variables available for analysis included histopathologic diagnosis (based on World Health Organization criteria), nuclear grade (based on Gynecologic Oncology Group criteria) and disease stage (according to the International Federation of Gynecology and Obstetrics system). The levels of PEA-15 phosphorylated at Ser104 and S116 and $\beta$-catenin were reported.

\section{Quantitative RT-PCR}

Quantitative RT-PCR was performed as described in Supplementary methods.

\section{In vivo tumorigenicity assay}

Four- to six-week-old female athymic BALB/C nu/nu mice were purchased from the Department of Veterinary Medicine and Surgery at MD Anderson. Mice were housed under specific pathogen-free conditions and were treated in accordance with the National Institutes of Health guidelines. To establish ovarian cancer xenografts, SKOV3.ip1 cells stably transfected with vector, PEA-15-WT, PEA-15-AA or PEA-15-DD were trypsinized, washed with PBS and centrifuged at 1200 r.p.m. for $5 \mathrm{~min}$. Cell pellets were resuspended in PBS at $4 \times 10^{6}$ cells $/ \mathrm{ml}$, and then cell suspension $(0.5 \mathrm{ml})$ was injected intraperitoneally under aseptic conditions into nude mice. After 6 weeks, all mice were euthanized, and samples of tumors were collected at biopsy and analyzed for PEA-15, $\beta$-catenin or CD31 by immunohistochemical staining.

\section{In vitro 3D Matrigel projection formation assay}

Three-dimensional Matrigel projection formation assays were performed in triplicate using $\mu$-Slide plates (ibidi $\mathrm{GmbH}$, Planegg, Germany) as described previously. ${ }^{51}$ SKOV3.ip1 cells stably transfected with vector, PEA-15-WT, PEA-15-AA or PEA-15-DD were trypsinized, washed with PBS and then resuspended with complete medium. For the bottom layer, $10 \mu \mathrm{l}$ of Matrigel was added on the $\mu$-Slide plate, and the plate was incubated in a $\mathrm{CO}_{2}$ incubator for $10 \mathrm{~min}$. Then, $50 \mu \mathrm{l}$ of cell suspension solution $\left(2 \times 10^{4}\right.$ cells in $2 \%$ Matrigel/complete medium) was added on the bottom layer. After a 24-h incubation in the $\mathrm{CO}_{2}$ incubator, cell network images were captured and analyzed for tube formation using S.CORE analysis software (S.CO LifeSciences GmbH, Hoehenkirchen, Germany).

\section{Migration assay}

Migration assays were performed in triplicate using a 48-well microchemotaxis chamber for $6 \mathrm{~h}$. The bottom wells were filled with $10 \%$ fetal bovine serum as an attractant. Results were quantitated by counting migrated cells in five randomly chosen high-power fields under a light microscope in triplicate.

\section{Soft agar assay}

Cells $\left(2 \times 10^{3}\right.$ cells/well) were resuspended in $2 \mathrm{ml}$ of $0.4 \%$ agarose solution in DMEM/F12 medium and overlayed onto the bottom agar layer (1\%) in six-well plates. The plates were incubated for 25 days, and colonies were stained with $200 \mu \mathrm{l}$ of iodo-nitrotetrazoliumchloride $(1 \mathrm{mg} / \mathrm{ml}$, SigmaAldrich) overnight. The number of stained colonies greater than $80 \mu \mathrm{m}$ in diameter was counted using the GelCount colony counting system (Oxford Optronix, Oxford, UK) according to the manufacturer's instructions. Means and standard deviations were calculated on the basis of the colony counts from triplicate wells.

Nuclear and cytosolic protein fractions

To isolate nuclear and cytosolic protein fractions from whole-cell lysates, cells were first trypsinized and washed with PBS. Cell pellets were resuspended with a hypotonic buffer $\left(10 \mathrm{mM}\right.$ Tris- $\mathrm{HCl}, \mathrm{pH} 8.0,3 \mathrm{mM} \mathrm{CaCl}{ }_{2}$, MgOAC, $0.1 \mathrm{mM}$ EDTA and protease inhibitors). After incubation for $15 \mathrm{~min}$ on ice, $10 \% \mathrm{NP}-40$ solution was added to make a $0.5 \%$ final concentration, and then the solution was vortexed for $1 \mathrm{~s}$. The homogenate was centrifuged at 5000 r.p.m. for $5 \mathrm{~min}$ to produce a cytosolic fraction and a crude nuclear fraction (pellet). The nuclear pellet was washed with hypotonic buffer and resuspended with $50 \mu$ l of buffer B $(20 \mathrm{mM} \mathrm{HEPES}, \mathrm{pH}$ 8.0, $1.5 \mathrm{mM} \mathrm{MgCl} 2,20 \mathrm{mM} \mathrm{KCl}$ and $0.2 \mathrm{mM}$ EDTA), and to this solution was added $50 \mu$ l of buffer C ( $20 \mathrm{mM}$ HEPES, pH $8.0,1.5 \mathrm{mM} \mathrm{MgCl} 2,800 \mathrm{mM} \mathrm{KCl}$, $0.2 \mathrm{mM}$ EDTA, $25 \%$ glycerol and $1 \%$ NP-40). After sonication, lysates were centrifuged at $12000 \mathrm{~g}$ for $15 \mathrm{~min}$. Supernatant were collected for analysis of nuclear fraction.

\section{Statistical analysis}

For experimental outcomes, descriptive statistics (mean and standard deviation) were summarized for each group. An analysis of variance model 
was used to compare the mean outcome values among the tested groups. $P<0.05$ was considered statistically significant. For tissue microarray data, descriptive statistics were summarized for the ovarian tumor group and the normal tissue group. The percentage of tumors with positive biomarker staining was compared between the two groups using the Wilcoxon ranksum test. Biomarker staining intensity was compared between the two groups using Fisher's exact test. Bonferroni method was used to adjust to multiple comparisons for each biomarker. Spearman's correlation coefficient was used to examine the correlation between any two biomarkers' positive staining percentages. Analyses were performed using SAS software, version 9.2 (SAS Institute Inc., Cary, NC, USA).

\section{CONFLICT OF INTEREST}

The authors declare no conflict of interest.

\section{ACKNOWLEDGEMENTS}

We thank Dr Mark Ginsberg (University of California, San Diego, CA, USA) for providing plasmid constructs PEA-15-AA and PEA-15-DD. We thank Sunita Patterson and Stephanie Deming of the Department of Scientific Publications at MD Anderson for their expert editorial assistance. This research was supported by the $\mathrm{NIH}$ through Grant CA127562 (NT Ueno) and through MD Anderson's Cancer Center Support Grant, CA016672.

\section{REFERENCES}

1 Siegel R, Ward E, Brawley O, Jemal A. Cancer statistics, 2011: the impact of eliminating socioeconomic and racial disparities on premature cancer deaths. CA Cancer J Clin 2011; 61: 212-236.

2 Renault F, Formstecher E, Callebaut I, Junier MP, Chneiweiss H. The multifunctional protein PEA-15 is involved in the control of apoptosis and cell cycle in astrocytes. Biochem Pharmacol 2003; 66: 1581-1588.

3 Glading A, Koziol JA, Krueger J, Ginsberg MH. PEA-15 inhibits tumor cell invasion by binding to extracellular signal-regulated kinase $1 / 2$. Cancer Res 2007 67: 1536-1544.

4 Bartholomeusz C, Itamochi H, Nitta M, Saya H, Ginsberg MH, Ueno NT. Antitumor effect of E1A in ovarian cancer by cytoplasmic sequestration of activated ERK by PEA15. Oncogene 2006; 25: 79-90.

5 Bartholomeusz C, Rosen D, Wei C, Kazansky A, Yamasaki F, Takahashi T et al. PEA-15 induces autophagy in human ovarian cancer cells and is associated with prolonged overall survival. Cancer Res 2008; 68: 9302-9310.

6 Bartholomeusz C, Gonzalez-Angulo AM, Kazansky A, Krishnamurthy S, Liu P, Yuan LX et al. PEA-15 inhibits tumorigenesis in an MDA-MB-468 triple-negative breast cancer xenograft model through increased cytoplasmic localization of activated extracellular signal-regulated kinase. Clin Cancer Res 2010; 16: 1802-1811.

7 Cadigan KM, Nusse R. Wnt signaling: a common theme in animal development Genes Dev 1997; 11: 3286-3305.

8 Morin PJ, Sparks AB, Korinek V, Barker N, Clevers H, Vogelstein B et al. Activation of beta-catenin-Tcf signaling in colon cancer by mutations in beta-catenin or APC. Science 1997; 275: 1787-1790.

9 Rubinfeld B, Souza B, Albert I, Muller O, Chamberlain SH, Masiarz FR et al. Association of the APC gene product with beta-catenin. Science 1993; 262: 1731-1734.

10 Morin PJ. beta-catenin signaling and cancer. Bioessays 1999; 21: 1021-1030.

11 Jin T, George Fantus I, Sun J. Wnt and beyond Wnt: multiple mechanisms control the transcriptional property of beta-catenin. Cell Signal 2008; 20: 1697-1704.

12 Yi F, Sun J, Lim GE, Fantus IG, Brubaker PL, Jin T. Cross talk between the insulin and Wnt signaling pathways: evidence from intestinal endocrine $\mathrm{L}$ cells. Endocrinology 2008; 149: 2341-2351.

13 Inoki K, Ouyang H, Zhu T, Lindvall C, Wang Y, Zhang X et al. TSC2 integrates Wnt and energy signals via a coordinated phosphorylation by AMPK and GSK3 to regulate cell growth. Cell 2006; 126: 955-968.

14 Choo AY, Roux PP, Blenis J. Mind the GAP: Wnt steps onto the mTORC1 train. Cell 2006; 126: 834-836.

15 Fiory F, Formisano P, Perruolo G, Beguinot F. Frontiers: PED/PEA-15, a multifunctional protein controlling cell survival and glucose metabolism. Am J Physiol Endocrinol Metab 2009; 297: E592-E601.

16 Krueger J, Chou FL, Glading A, Schaefer E, Ginsberg MH. Phosphorylation of phosphoprotein enriched in astrocytes (PEA-15) regulates extracellular signalregulated kinase-dependent transcription and cell proliferation. Mol Biol Cell 2005 16: 3552-3561

17 Yu D, Wolf JK, Scanlon M, Price JE, Hung MC. Enhanced c-erbB-2/neu expression in human ovarian cancer cells correlates with more severe malignancy that can be suppressed by E1A. Cancer Res 1993; 53: 891-898.
18 Kenny PA, Lee GY, Myers CA, Neve RM, Semeiks JR, Spellman PT et al. The morphologies of breast cancer cell lines in three-dimensional assays correlate with their profiles of gene expression. Mol Oncol 2007; 1: 84-96.

19 Lee JM, Dedhar S, Kalluri R, Thompson EW. The epithelial-mesenchymal transition: new insights in signaling, development, and disease. J Cell Biol 2006; 172 973-981.

20 He TC, Sparks AB, Rago C, Hermeking H, Zawel L, da Costa LT et al. Identification of c-MYC as a target of the APC pathway. Science 1998; 281: 1509-1512.

21 Tetsu O, McCormick F. Beta-catenin regulates expression of cyclin D1 in colon carcinoma cells. Nature 1999; 398: 422-426.

22 Schwartz DR, Wu R, Kardia SL, Levin AM, Huang CC, Shedden KA et al. Novel candidate targets of beta-catenin/T-cell factor signaling identified by gene expression profiling of ovarian endometrioid adenocarcinomas. Cancer Res 2003, 63: $2913-2922$.

23 Araki Y, Okamura S, Hussain SP, Nagashima M, He P, Shiseki M et al. Regulation of cyclooxygenase-2 expression by the Wnt and ras pathways. Cancer Res 2003; 63: 728-734

24 Chang YS, di Tomaso E, McDonald DM, Jones R, Jain RK, Munn LL. Mosaic blood vessels in tumors: frequency of cancer cells in contact with flowing blood. Proc Natl Acad Sci USA 2000; 97: 14608-14613.

25 Chou FL, Hill JM, Hsieh JC, Pouyssegur J, Brunet A, Glading A et al. PEA-15 binding to ERK $1 / 2$ MAPKs is required for its modulation of integrin activation. $J \mathrm{Bio} / \mathrm{Chem}$ 2003; 278: 52587-52597.

26 Formstecher E, Ramos JW, Fauquet M, Calderwood DA, Hsieh JC, Canton B et al. PEA-15 mediates cytoplasmic sequestration of ERK MAP kinase. Dev Cell 2001; 1 239-250.

27 Hill JM, Vaidyanathan H, Ramos JW, Ginsberg MH, Werner MH. Recognition of ERK MAP kinase by PEA-15 reveals a common docking site within the death domain and death effector domain. EMBO J 2002; 21: 6494-6504.

28 Whitehurst AW, Robinson FL, Moore MS, Cobb MH. The death effector domain protein PEA-15 prevents nuclear entry of ERK2 by inhibiting required interactions. J Biol Chem 2004; 279: 12840-12847.

29 Renganathan $H$, Vaidyanathan $H$, Knapinska A, Ramos JW. Phosphorylation of PEA-15 switches its binding specificity from ERK/MAPK to FADD. Biochem J 2005 390: 729-735.

30 Trencia A, Perfetti A, Cassese A, Vigliotta G, Miele C, Oriente F et al. Protein kinase B/Akt binds and phosphorylates PED/PEA-15, stabilizing its antiapoptotic action. Mol Cell Biol 2003; 23: 4511-4521.

31 Cukierman E, Pankov R, Stevens DR, Yamada KM. Taking cell-matrix adhesions to the third dimension. Science 2001; 294: 1708-1712.

32 Formisano P, Ragno P, Pesapane A, Alfano D, Alberobello AT, Rea VE et al. PED/ PEA-15 interacts with the $67 \mathrm{kDa}$ laminin receptor and regulates cell adhesion migration, proliferation and apoptosis. J Cell Mol Med 2012; 16: 1435-1446.

33 Liu C, Li Y, Semenov M, Han C, Baeg GH, Tan Y et al. Control of beta-catenin phosphorylation/degradation by a dual-kinase mechanism. Cell 2002; 108 837-847.

34 Bienz M. beta-Catenin: a pivot between cell adhesion and Wnt signalling. Curr Biol 2005; 15: R64-R67.

35 Yost C, Torres M, Miller JR, Huang E, Kimelman D, Moon RT. The axis-inducing activity, stability, and subcellular distribution of beta-catenin is regulated in Xenopus embryos by glycogen synthase kinase 3. Genes Dev 1996; 10: 1443-1454.

36 Cross DA, Alessi DR, Cohen P, Andjelkovich M, Hemmings BA. Inhibition of glycogen synthase kinase-3 by insulin mediated by protein kinase B. Nature 1995; 378: 785-789.

37 Hino S, Tanji C, Nakayama Kl, Kikuchi A. Phosphorylation of beta-catenin by cyclic AMP-dependent protein kinase stabilizes beta-catenin through inhibition of its ubiquitination. Mol Cell Biol 2005; 25: 9063-9072.

38 Taurin S, Sandbo N, Qin Y, Browning D, Dulin NO. Phosphorylation of beta-catenin by cyclic AMP-dependent protein kinase. J Biol Chem 2006; 281: 9971-9976.

39 Fang D, Hawke D, Zheng Y, Xia Y, Meisenhelder J, Nika $\mathrm{H}$ et al. Phosphorylation of beta-catenin by AKT promotes beta-catenin transcriptional activity. J Biol Chem 2007; 282: 11221-11229.

40 He XC, Yin T, Grindley JC, Tian Q, Sato T, Tao WA et al. PTEN-deficient intestinal stem cells initiate intestinal polyposis. Nat Genet 2007; 39: 189-198.

41 Cheadle C, Nesterova M, Watkins T, Barnes KC, Hall JC, Rosen A et al. Regulatory subunits of PKA define an axis of cellular proliferation/differentiation in ovarian cancer cells. BMC Med Genomics 2008; 1: 43

42 This is a list of target genes of Wnt/beta-catenin signaling. Updated December 2009; Available from http://www.stanford.edu/ rnusse/pathways/targets.html.

43 Rosano L, Spinella F, Di Castro V, Nicotra MR, Dedhar S, de Herreros AG et al. Endothelin-1 promotes epithelial-to-mesenchymal transition in human ovarian cancer cells. Cancer Res 2005; 65: 11649-11657.

44 Yoshida S, Furukawa N, Haruta S, Tanase Y, Kanayama S, Noguchi T et al. Expression profiles of genes involved in poor prognosis of epithelial ovarian carcinoma: a review. Int J Gynecol Cancer 2009; 19: 992-997. 
45 Skurk C, Maatz H, Rocnik E, Bialik A, Force T, Walsh K. Glycogen-synthase kinase3beta/beta-catenin axis promotes angiogenesis through activation of vascular endothelial growth factor signaling in endothelial cells. Circ Res 2005; 96: 308-318.

46 Zohny SF, Fayed ST. Clinical utility of circulating matrix metalloproteinase-7 (MMP-7), CC chemokine ligand 18 (CCL18) and CC chemokine ligand 11 (CCL11) as markers for diagnosis of epithelial ovarian cancer. Med Oncol 2010; 27: 1246-1253.

47 li M, Yamamoto H, Adachi Y, Maruyama Y, Shinomura Y. Role of matrix metalloproteinase-7 (matrilysin) in human cancer invasion, apoptosis, growth, and angiogenesis. Exp Biol Med (Maywood) 2006; 231: 20-27.

48 Ramos JW, Kojima TK, Hughes PE, Fenczik CA, Ginsberg MH. The death effector domain of PEA-15 is involved in its regulation of integrin activation. $J$ Biol Chem 1998; 273: 33897-33900.
49 Ramos JW, Hughes PE, Renshaw MW, Schwartz MA, Formstecher E, Chneiweiss H et al. Death effector domain protein PEA-15 potentiates Ras activation of extracellular signal receptor-activated kinase by an adhesion-independent mechanism. Mol Biol Cell 2000; 11: 2863-2872.

50 Bock BC, Tagscherer KE, Fassl A, Kramer A, Oehme I, Zentgraf HW et al. The PEA-15 protein regulates autophagy via activation of JNK. J Biol Chem 2010; 285: 21644-21654.

51 Lee GY, Kenny PA, Lee EH, Bissell MJ. Three-dimensional culture models of normal and malignant breast epithelial cells. Nat Methods 2007; 4: 359-365.

(c) Oncogenesis is an open-access journal published by Nature Publishing SOMERIGHISRESERVED Group. This work is licensed under the Creative Commons AttributionNonCommercial-Share Alike 3.0 Unported License. To view a copy of this license, visit http://creativecommons.org/licenses/by-nc-sa/3.0/

Supplementary Information accompanies the paper on the Oncogenesis website (http://www.nature.com/oncsis) 